\title{
Design of Information and Technology Based Teaching Materials in Mathematics Subjects of IT High School Pekanbaru Students
}

\author{
Heni Rahmadani, Yenita Roza*, Atma Murni \\ Program Studi Magister Pendidikan Matematika, Universitas Riau \\ *e-mail : yenita.roza@lecturer.unri.ac.id
}

\begin{abstract}
This research is based on the low mathematical representation ability of students and the lack of textbooks used by teachers in presenting teaching material. This study aims to describe the results of the development of information technologybased teaching materials to improve the mathematical representation ability of students in class X Trigonometry Function Materials that are valid, practical, and effective. The model used in this research development is the ADDIE development model, namely Analysis, Design, Development, Implementation, and Evaluation. The research instruments used in this article are validation sheets (validity aspects), teacher assessment sheets and student assessment sheets (practical aspects), and mathematical representation ability tests (effectiveness aspects). Analysis of the data used in this research is parametric statistics, the t-test with the help of SPSS 18.00 using the Independent-Sample t-Test. This research resulted in a product of teaching materials based on information and technology in valid mathematics $(87.11 \%)$, practical $(90.81 \%)$ and effective $(0.043<0.05)$.
\end{abstract}

Keyword: Teaching Materials; Information and Technology; Discovery Learning Models; Mathematical Representation Ability.

\section{INTRODUCTION}

Teaching material is one of the important factors in supporting the successful implementation of the 2013 curriculum. Teaching material is a set of systematically compiled learning tools containing learning material, methods, strategies, approaches, limitations and ways of evaluating systematically and attractively designed in order to achieve expected goal (Erna Yayuk, 2019). Teaching material is also defined as any form of material or material arranged systematically that is used to assist teachers in implementing the learning process to create an environment or atmosphere that allows for learning (Saluky, 2016). This understanding illustrates that a teaching material should be designed according to the rules of instructional and existing curriculum. However, at present, the availability of teaching materials in accordance with the 2013 curriculum is considered being very lacking. Based on the experience of researchers as teachers, some information is obtained that: 1) teaching materials available do not help students' understanding; 2) the teacher has difficulty in making teaching materials in accordance with the 2013 Curriculum (Heni Rahmadani, Yenita Roza, 2018). Based on the results of interviews with several students at Al-Bayyinah IT High School in December 2017, it can be concluded that: 1) teachers sometimes give LKPD students; 2) students have difficulty using existing media / books; 3) textbooks in circulation are difficult for students to understand; 4) students have difficulty in understanding abstract mathematical material (Heni Rahmadani, Yenita Roza, 2018). 
Based on the weaknesses of the teaching materials mentioned above, the teacher needs to develop teaching materials that are in accordance with the 2013 curriculum. Teaching materials that are developed must be complete, both in terms of activities undertaken by students, sample questions and practice questions, especially for abstract material. , able to facilitate students in understanding the concept. Permendikbud 2016 explains the standard content of primary and secondary education for students, must show the positive attitude in mathematics, namely: logical, critical, careful and thorough, honest, responsible, and not easily give up in solving problems, as a form of implementing habits in inquiry and mathematical exploration. One of the objectives of learning mathematics in the 2013 curriculum is that students are expected to have the mathematical representation, this is stated in Minister of Education and Culture Regulation No. 58 of 2014 (Herlina, Edy Yusmin, 2017). In the 2013 curriculum the ability of mathematical representation is very much needed by students given that today science and technology are developing very rapidly and allows anyone to obtain information quickly and easily with abundant resources from various places and anywhere in the world.

The ability of mathematical representation is very important and must be instilled early on both at school, at home and in the community. The representation is done in supporting students' understanding between various mathematical concepts that are related, and in applying mathematical concepts to situations of realistic problems through modeling (Septia Wahyuni, 2012). McCoy, Baker, and Little suggested that one of the best ways to help students understand mathematics is through mathematical representation (Kartini Hutagaol, 2013). The ability of mathematical representation is also very important for students and is closely related to communication skills and problem solving (Muhamad Sabirin, 2014). The ability of mathematical representation is needed by students to find and make ways of thinking in communicating mathematical ideas from abstract to concrete, so that it is easier to understand (Leo Adhar Effendi, 2012). A problem that is considered complex and complex can be simplified if the strategy and utilization of mathematical representations are used in accordance with the problem. Therefore, the selection of representation models possessed by students plays an important role in decision-making strategies for solving mathematical problems that are appropriate and accurate.

The results of the preliminary study show that the mathematical representation ability of students is still relatively low, seen from several indicators: 1) students have not been able to express mathematical ideas into one form of images, mathematical notation; and 2) students tend not to be able to answer questions that are not in accordance with the example given by the teacher. There are several studies which state that students' mathematical representation abilities are very limited (Syarifah Fadillah, 2011), the ability of representation of students in general is still low (Sri Rezeki, 2017), learners tend to imitate teacher procedures (Amri, 2009). Based on these conditions a learning model is needed that helps students to discover their own concepts of mathematics learning. Many factors can affect the improvement of students' mathematical representation ability in learning, one of them is the use of teaching materials, learning resources, learning strategies and learning models. With the development of technology, currently starting to develop various teaching materials that follow the development of technology including IT-based teaching materials.

IT-based teaching materials are technology-based teaching materials as a tool in processing data consisting of efforts to process, obtain, compile, store, manipulate data in various ways to produce quality information (Anggita Maharani, 2017). In learning 
activities, the use of IT teaching materials enables students to learn a basic competency in a coherent, systematic, interactive and innovative way. Some studies suggest that: 1) the use of Geogebra and Microsoft Mathematics software can help educators deliver abstract mathematical material and can improve the ability to think logically (Aminah Ekawati, 2016); and 2) the use of Microsoft Mathematics applications can help students find mathematical calculus concepts and students are able to present solutions and provide feedback to educators in the learning process (Rina Oktaviyanthi, 2014). Through the use of IT-based media, students are prepared to interpret all information and create it into knowledge so that they can then use and evaluate those created by others (Hasan Mahmud Halidi, 2015). Based on these explanations, it can be understood that IT-based teaching materials are all materials that can be learned by students independently and displays a complete figure of competencies and sub-competencies that will be mastered by students through a learning process that encourages the involvement of students in an actively pleasing.

In addition to aspects of IT-based teaching materials, efforts that need to be made by teachers to improve students' mathematical representation ability are to improve the effectiveness of mathematics learning through the use of learning models. At present many learning models are used in the 2013 curriculum, one of which is the discovery learning model. Discovery learning model is a learning model that is defined as a learning process that occurs when students are not presented with a lesson in its final form, but it is expected that students organize themselves through teacher guidance (Yusem Ba'ru, 2016). Previous research related to the use of discovery learning models revealed that there is a positive effect of learning by using discovery learning models in improving mathematical, critical thinking skills (Yusmanto, 2017). Discovery learning has advantages, namely: helping students to improve and enhance skills and cognitive processes so that the knowledge gained through this method is a very personal and powerful because it strengthens understanding, memory, and transfer (Salo, 2017). Mathematical concepts that they find themselves will be very useful to find other concepts in learning mathematics. Students can apply mathematical concepts to more complex things, including applying mathematical thinking patterns in everyday life.

Some development researches on the development of teaching materials has been done before. Research on developing teaching materials based on a scientific approach improves students' mathematical literacy abilities (Elly Mardiana, 2018), development of computer-based mathematics teaching materials for students (Ruslan Saputra, Irham Falahudin, 2016), and the development of problem-based mathematics teaching materials oriented towards mathematical problem-solving abilities and mathematics learning achievement (Jeaniver Yuliane Kharisma, 2018). To help teachers implement the 2013 curriculum, development of valid, practical and effective teaching materials is needed. Researchers are interested in developing information and technology-based teaching materials with discovery learning models in order to obtain valid, practical, and effective teaching materials to improve the mathematical representation ability of students in class X SMA.

\section{RESEARCH METHOD}

The research method used is the ADDIE model, namely Analysis, Design, Development, Implementation, and Evaluation. Products developed in this study have good quality measured through validity, practicality, and effectiveness. The components 
of validity are content eligibility, linguistics, presentation, and graphics (Depdiknas, 2008). Sukardi stated that practicality can be seen in aspects of: 1) utility; 2) time; 3) Attraction; 4) easily interpreted by the teacher; and 5) equality (Sukardi, 2008). Van Den Akker stated "effectiveness refers to the level of consistency of experience and results of interventions with the intended objectives" (Rochmad, 2011). Based on this explanation, the development of this teaching material can be implemented well if it meets the criteria of validity, practicality, and effectiveness. The steps in this study include:

The analysis phase, the efforts made: analyzing the need for the development of teaching materials and analyzing the feasibility and development requirements that include teacher performance analysis, student character analysis, and curriculum analysis. Process: through interviews, observation and documentation. Expected results: follow up on the development of IT-based teaching materials to improve students' mathematical representation abilities. The design phase, the efforts made: compiling IT-based teaching materials that include material and technology, collecting references, and compiling instruments in the form of a questionnaire of validity, practicality and tests of mathematical representation abilities. Process: Source or reference and use of Macromedia Flash and MS Power Point software. Expected results: neatly arranged teaching materials and initial drafts of teaching material development. The development phase, the efforts made: producing or making products and the validatory to assess the material and design of teaching materials. Process: validation sheet for material experts and technology experts. Expected results: valid material and design of teaching materials. Implementation phase, the efforts made: conducting a trial of small groups (9 people) and large groups (17 people). Expected results: students' responses stating the material and design of practical teaching materials. Evaluation phase, the efforts made: utilizing teaching materials during 9 meetings to see the mathematical representation ability of students. Then, at the last meeting a written test was conducted to see the effectiveness of the use of teaching materials. Process: test instrument for students' mathematical representation ability. Expected results: there are differences in the ability of mathematical representation of students who use teaching materials that are developed and those that do not use teaching materials.

The research instrument used was a validation sheet (the aspect of validity) involving 3 lecturers and 1 mathematics teacher, a student assessment sheet (practicality aspect) involving 9 people on a small group trial and 17 people on a large group trial, and a representation ability test mathematical students (aspects of effectiveness) involving 38 people. Questionnaire and test of students' mathematical representation ability were analyzed using quantitative descriptive test and parametric statistics with t-test using SPSS 18.00 .

\section{RESULTS AND DISCUSSION}

In developing this teaching material, the development procedure that has been carried out consists of five stages. Following are the results of the five stages of the development of teaching materials with the ADDIE model.

\section{The Analysis Phase}

At this stage several activities were carried out, namely teacher performance analysis, student characteristics and curriculum. Teacher performance analysis includes three aspects, namely: 1) aspects of the type of teaching materials possessed by teachers; 
2) aspects of the use of teaching materials in learning; and 3) aspects of the use of technology in learning. The results of teacher performance analysis show that: 1) some teachers only use teaching materials from the government and some use additional resources; 2) teaching materials have not been developed independently; and 3) some teachers have not utilized the facilities provided by schools such as invocations and computer laboratories. Based on this information, teachers have not fully used IT-based teaching materials that support students' mathematical abilities which are characterized by a lack of use of technology in learning activities. Therefore, researchers developed ITbased teaching materials to improve the ability of mathematical representation in the Trigonometry Function Graph material.

At this stage, the researcher also analyzes the characteristics of the students which include two aspects, namely: 1) the aspect of mathematical representation ability; and 2) aspects of student activities in the learning process. The results of the analysis of student characteristics through observation and interviews illustrate that: 1) students' mathematical representation ability is still low; 2) the involvement of students in learning mathematics is still low; and 3) students are less interested when working on the matter of drawing the Trigonometry Function Graph. The results of these observations and interviews encourage the author to improve students' mathematical representation abilities through IT-based teaching materials. Researchers conducted a curriculum analysis phase that included three aspects, namely: 1) developing indicators of competency achievement; 2) material in mathematics learning; and 3) the mathematics learning model used. The results of curriculum analysis are obtained through observation and documentation which provides information that: 1) the CPI has not been able to measure the achievement of $\mathrm{KD}$; 2) learners need material about unit circles to match the KD 3.10 sound, which is to explain trigonometric functions using unit circles; and 3) the learning model applied has not varied.

\section{The Design Phase}

At this stage, researchers design IT-based teaching materials based on the results of teacher performance analysis, student characteristics analysis, and curriculum analysis that has been done. The teaching material designed is IT-based and packaged in a power point and uses a number of flash movies and geogebra applications in the Trigonometry Function Graph material for nine meetings with complete material that has been adjusted to the GPA that has been developed so that learning objectives are achieved. This IT-based teaching material consists of the front page / cover, home, main menu, info, basic competencies and indicators of competency achievement, concept maps, apperception, motivation, activities, evaluation, discussion, and author profile.

\section{The Development Phase}

At this stage, researchers develop IT-based teaching materials that are adapted to designs that have been made previously using Microsoft Office Power Point and Macromedia Flash software. The following is the development of information and technology-based teaching materials. 


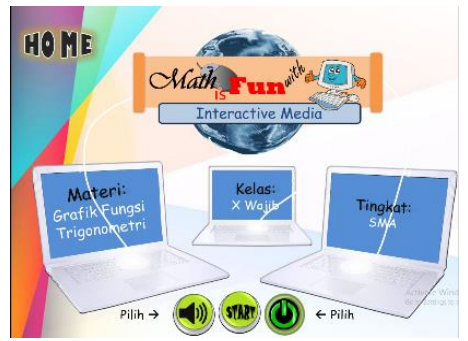

Gambar 1.a

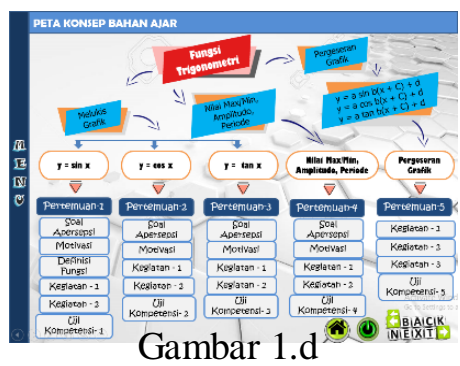

Gambar 1.d

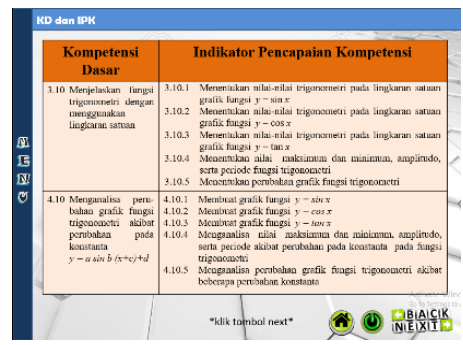

Gambar 1.b
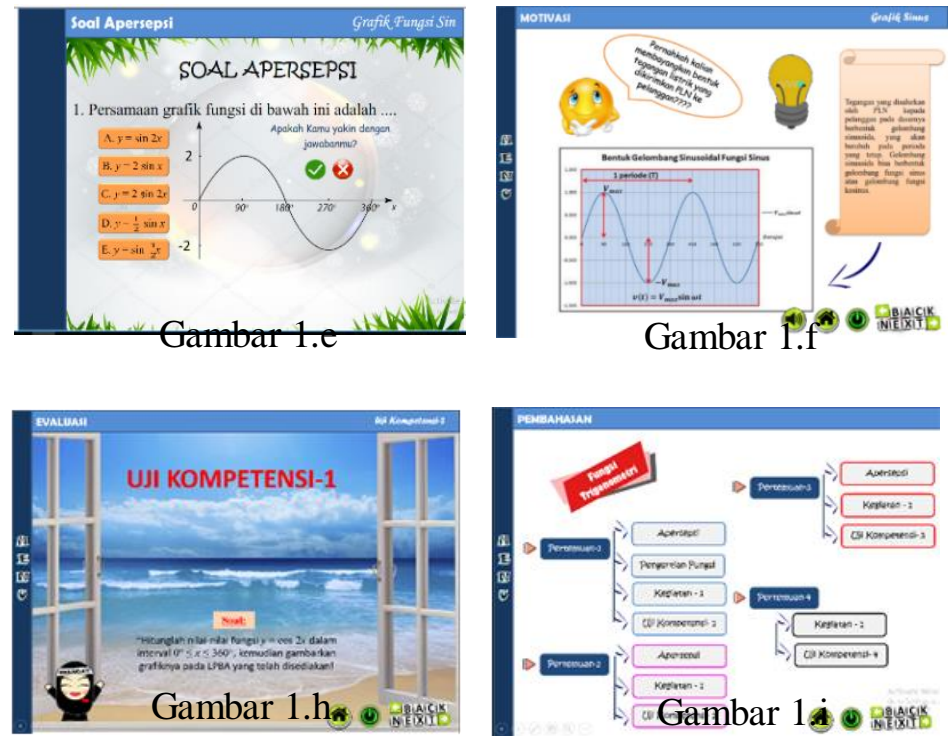

Figure 1. Results of Development of Information and Technology

Based Teaching Materials

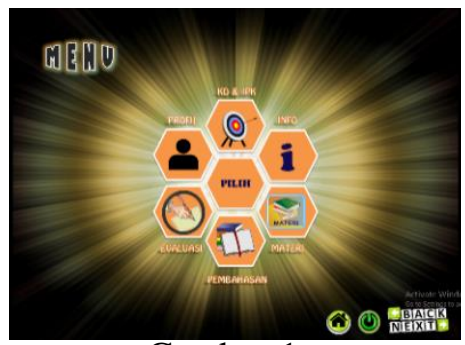

Gambar 1.c

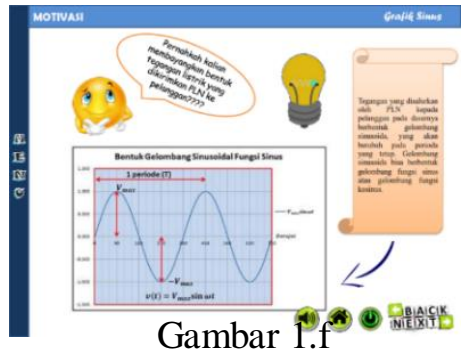

In Figure 1.a, HOME, there are three buttons, the soundbutton which functions to activate and deactivate the sound, the start button which if clicked will go to the main menu page, and the exit button which if clicked will go to the exit page. Besides this page is also accompanied by the words "HOME" which indicates that this page is named "HOME". In Figure 1.b, shows the Basic Competencies (KD) and Competency Achievement Indicators (GPA) that researchers have compiled in accordance with the syllabus. Students can find out what indicators must be achieved in this Trigonometry Function Graph material. In Figure 1.c, the main menu page contains the menus contained in teaching materials, including the profile button, KD and GPA, Info, Material, Discussion, Evaluation, and Profile. To go to a page on a menu, the user must click on the menu button. The menu page is displayed so that students know what is contained in this IT-based teaching material. In Figure 1.d, a concept map that contains a description of the material contained in teaching materials for five meetings. The concept map presentation aims to make it easier for students to know the titles and subtitles to be studied. In Figure 1.e, the value slide will appear automatically when the user has answered all the questions contained in this teaching material. In Figure 1.f, the motivation page contains pictures 
along with a brief explanation related to the material. In Figure 1.g, this page contains material to be studied by users consisting of several activities and in accordance with the subtitles studied at each meeting. In Figure 1.h, the evaluation page contains the questions that will be tested at the end of the lesson. In Figure 1.i., this page contains alternative answers to all questions contained in this IT-based teaching material and is designed for five meetings.

Teaching materials that have been developed are then validated by 4 (four) validators. The validator consisted of three mathematics education lecturers with S2 and S3 education criteria, and one high school mathematics teacher with S2 education criteria. Product viability can be seen based on the rating of the validator. The results of the validation of IT-based teaching materials are presented in table 1 below.

Table 1. Results of Validation of Information and Technology

Based Teaching Materials

\begin{tabular}{|c|c|c|c|c|c|c|}
\hline No & Material Aspects & Percentage & Criteria & Media Aspects & Percentage & Criteria \\
\hline 1 & Preliminary Aspects & $88,33 \%$ & Valid & Display Aspects & $83,70 \%$ & Very Valid \\
\hline 2 & Content Aspect & $84,44 \%$ & Very Valid & Usage Aspects & $85,56 \%$ & Very Valid \\
\hline 3 & Learning Aspects & $88,72 \%$ & Very Valid & Utilization Aspects & $84,76 \%$ & Very Valid \\
\hline 4 & $\begin{array}{l}\text { Task / Exercise and } \\
\text { Evaluation Aspects }\end{array}$ & $90,48 \%$ & Very Valid & & & \\
\hline 5 & Summary Aspects & $77,78 \%$ & Valid & & & \\
\hline & Mean & $85,95 \%$ & Very Valid & & $84,67 \%$ & Very Valid \\
\hline
\end{tabular}

Based on Table 1 above it can be seen that the average validity for IT-based teaching material as a whole is $85.95 \%$ with the criteria of "Very Valid", while the average validity for media or technology for IT-based teaching materials as a whole is $84,67 \%$ with the criteria "Very Valid". Thus, the average value of the validity of IT-based teaching materials meets the criteria of "Very Valid". Thus, IT-based teaching materials and research instruments are appropriate to be used in a small group and large group trials.

\section{Implementation Phase}

After making improvements according to the suggestions of the validator, then a small group and a large group test is performed. This legibility test was conducted in a small group of 9 XIB grade students at Al Bayyinah Pekanbaru IT High School who had never received a trigonometric function graphic material and had heterogeneous abilities. This small group trial was conducted on 9-11 October 2019 outside school hours. This stage is carried out by distributing response questionnaires and then filling in according to their respective opinions. The results of the assessment of students on readability in table 2 follows:

Table 2. Small Group Trial Results

\begin{tabular}{lcc}
\hline \multicolumn{1}{c}{ Rated aspect } & Percentage & Criteria \\
\hline Ease of Use & $91,11 \%$ & Very Practical \\
Appearance Aspects & $80,74 \%$ & Practical \\
Presentation Aspects & $91,62 \%$ & Very Practical \\
Readability Aspects & $91,85 \%$ & Very Practical \\
\hline \multicolumn{1}{c}{ Mean } & $87.80 \%$ & Very Practical \\
\hline
\end{tabular}


Based on Table 2, the average practicality value of teaching materials developed reaches a value of $87.80 \%$ with the category "Very Practical". The category indicates that overall teaching materials are considered good. After testing the readability and revising teaching materials, the researchers conducted a large group trial on the $\mathrm{XI}^{\mathrm{D}}$ grade students of SMA IT Al Bayyinah Pekanbaru, totaling 17 students with heterogeneous abilities. This trial was carried out on 15, 18, 22, 25, and 28 October 2019. By using the same student response questionnaire on the readability test, students were also asked to fill in the questionnaire according to their respective understandings. The results of the assessment of students regarding practicality in table 3 follows:

Table 3. Results of Large Group Trials

\begin{tabular}{lcc}
\hline \multicolumn{1}{c}{ Rated aspect } & Percentage & Criteria \\
\hline Ease of Use & $97,26 \%$ & Very Practical \\
Appearance Aspects & $81,59 \%$ & Very Practical \\
Presentation Aspects & $97,80 \%$ & Very Practical \\
Readability Aspects & $98,57 \%$ & Very Practical \\
\hline \multicolumn{1}{c}{ Rata-rata } & $93.81 \%$ & Very Practical \\
\hline
\end{tabular}

Based on Table 3 above, obtained an average value of developed teaching material practicality of $93.81 \%$ with the category "Very Practical". The teaching material used as a whole is considered being good and based on comments and suggestions from students. Based on the results of the analysis obtained information that practical teaching materials to be developed.

\section{Evaluation Phase}

Evaluation is carried out to measure the achievement of the objectives of developing teaching materials that are developed. One of the goals of the development is to see the effectiveness of the use of teaching materials through increasing the mathematical representation ability of students after using teaching materials. The test results of the mathematical representation ability of the experimental class and the control class were analyzed by parametric statistical techniques, namely the t-test using the help of SPSS Program version 18.00 for windows. However, before conducting the t-test, a normality and homogeneity test is first performed. In the normality test, both data from the experimental class and the control class meet the normality assumption $(0.145>, 05$ and $0.168>0.05)$. In the homogeneity test, the variance of the experimental group and the control group is the same or homogeneous $(0.387>0.05)$. Prerequisite analysis has been fulfilled so that the difference test is done using the Independent Sample Sample t-Test. The results of the analysis of mathematical representation ability tests are presented in Table 4 below.

Table 4. T-Test of Experiment Class and Control Class

\begin{tabular}{lllcccc}
\hline \multicolumn{1}{c}{ Class } & $\mathrm{N}$ & Mean & Standard Deviation & $\mathrm{t}$ & df & Sig. (2-tailed) \\
\hline Eksperiment- & 20 & 21.20 & 1.989 & 12.614 & 36 & 0.043 \\
Control & 18 & 20.83 & 1.654 & & & \\
\hline
\end{tabular}

Based on Table 6 above obtained data that a significant value of $0.043<\alpha=0.05$, which means $H 0$ rejected or $H 1$ accepted. That is, there are differences in mathematical representation capabilities between students who use IT-based teaching materials and students who do not use IT-based teaching materials. Thus, it can be concluded that the 
results of the mathematical representation ability of the experimental class students are better than the results of the mathematical representation ability of the students of the control class.

Based on the results of the explanation above, this research produces technologybased teaching materials and information through discovery learning models to improve students' mathematical representation ability in class $\mathrm{X}$ trigonometric functions that are valid (average overall aspects of material validation are $87.27 \%$ with criteria "Very Valid"; and the average overall aspect of technology validation is $87.11 \%$ with the criteria "Very Valid"). Information and technology-based teaching materials with this discovery learning model are appropriate and can be said to be feasible to use. Teaching material is said to be valid, if expert judgment shows that the development of the device is based on a string theory and has internal consistency, is there is an interrelation between the components in the device being developed (Muhammad Khalifah Mustami, 2015). In addition, according to the Ministry of National Education that the criteria assessed by experts include a component of content eligibility, a linguistic component, a presentation component, and a graphic component. (Musa Thahir, Yenita Roza, 2018). Teaching materials that have met the validity aspects and after being corrected according to the advice of the validator, then readability and practicality tests are carried out. In small group trials shows the average practicality value of teaching materials developed reached a value of $87.80 \%$ with the category "Very Practical". While large group trials show the average value of the practicality of teaching materials developed by $93.81 \%$ with the category "Very Practical". These results are in line with research which says that practical computer-based mathematics teaching materials are used in mathematics learning on the Pythagorean theorem material conducted by (Ruslan Saputra, Irham Falahudin, 2016).

Based on the results of validation and practicality shows that IT-based teaching materials have met the requirements of valid and practical teaching materials. IT-based teaching materials must also meet the requirements of effective teaching materials. The effectiveness test results obtained that the significance value is smaller than $\alpha=0.05$ $(0.043<0.05)$. That is, an experimental class that uses IT-based teaching materials has better mathematical representation capabilities than a control class that does not use ITbased materials. The results of this study are strengthened by previous research that learning mathematics with discovery learning models there is an increase in the mathematical representation ability of class IX-G students in SMP Negeri 2 Bandung (Siti Tuti Alawiyah, 2019). The mathematical representation ability of junior high school students who get discovery learning is better than students who use conventional learning (Widya Kusumaningsih, 2017). Based on these results it can be concluded that the discovery learning model can influence the students' mathematical representation ability. The results of this study indicate that the application of ICT-based mathematics teaching materials produced is effective in achieving minimum completeness criteria and students' responses to ICT-based mathematics teaching materials are interesting and easy to understand (Oktaria, Sugeng Sutiarso, 2016). In addition, the results of this study are also strengthened by the results of studies that show that the development of Geogebra-based teaching materials on the Android version has been categorized as valid, practical and has a potential effect on student achievement and activity levels (Heri Budiman, 2017). Development of IT-based teaching materials using discovery learning models in mathematics, especially trigonometric functions graphic material in accordance with the problems found and in accordance with the characteristics of students and development 
needs such as the applicable curriculum and learning objectives in the graphic material trigonometric functions. In addition, this success is due to the discovery learning model which is a learning model that involves students actively mobilizing all their abilities to search and investigate systematically, critically, and logically so that students can find their own concepts of material (Shofura Farah Diba, Haninda Bharata, 2018). Thus, the discovery learning model is expected to be able to direct students to find the concepts and principles of the material that are expected to influence the ability of students to represent things that are found in the learning process.

The development of information and technology-based teaching materials on a trigonometric function graphic material conducted in this research is one of the efforts to develop teaching materials in mathematics, especially on a trigonometric function graphic material. Therefore, information and technology-based teaching materials with discovery learning models are very well used and is a solution to help students and teachers in learning mathematics that aims to improve the mathematical representation ability of students in solving mathematical problems.

\section{CONCLUSION}

Based on the results of the research and discussion in this article which has been stated previously, it can be concluded that the research produced IT-based teaching materials that are: 1) valid (the average overall aspect of material validation is $87.27 \%$ with the criteria "Very Valid"; and average average overall aspects of technology validation by $87.11 \%$ with the criteria "Very Valid"); 2) practical (average overall aspects obtained from the assessment of students by $87.80 \%$ with the category "Very Practical" at the readability test stage and by $93.81 \%$ with the category "Very Practical" on the practicality test); and 3) effective (Sig value $0.043<$ Sig value (2-tailed) 0.05 ). Thus, the mathematical representation ability of students after using IT-based teaching materials is better than before using information-based teaching materials and technology.

Based on the results of development research that has been done, the researcher suggests the following: 1) For teachers, it should consider the use of IT-based teaching materials with the application of discovery learning models in mathematics learning to improve mathematical representation abilities; 2) For students, it is hoped that they will be more active and more diligent in learning in order to be able to improve the ability of students' effective mathematical representation; 3) For school principals, as input for fostering teachers and students to expand the development of teaching materials, especially teaching materials in mathematics learning; and 4) For other researchers, they should be able to minimize the limitations of the researchers so that they are better and continue to develop teaching materials for other aspects of research in a broader study, such as in different materials, populations, and other mathematical abilities.

\section{REFERENCES}

Aminah Ekawati. (2016). Penggunaan Software Geogebra dan Microsoft Mathematic Dalam Pembelaran Matematika. Math Didactic: Jurnal Pendidikan Matematika, 2(3), 148-153. https://doi.org/https://doi.org/10.33654/math.v2i3.43

Amri. (2009). Peningkatan Kemampuan Representasi Matematik Siswa SMP melalui Pembelajaran dengan Pendekatan Induktif-Deduktif. Universitas Pendidikan Indonesia. 
Anggita Maharani. (2017). Pengembangan Bahan Ajar Matematika Berbasis Macromedia Flash Materi Operasi Bilangan Real SMK Teknologi \& Rekayasa. Jurnal Teori Dan Riset Matematika (TEOREMA), 2(1), 1-10.

Depdiknas. (2008). Panduan Pengembangan Bahan Ajar. Jakarta: Direktorat Pembinaan SMA.

Elly Mardiana. (2018). Pengembangan Bahan Ajar Berbasis Pendekatan Saintifik Meningkatkan Kemampuan Literasi Matematika Siswa. In PRISMA, Prosiding Seminar Nasional Matematika (pp. 87-91).

Erna Yayuk. (2019). Pengembangan Bahan Ajar Pembelajaran Matematika untuk Mahasiswa PGSD Semester 6. Scholaria: Jurnal Pendidikan dan Kebudayaan, 9(2), 171-182. https://doi.org/https://doi.org/10.24246/j.js.2019.v9.i2.p172-182

Hasan Mahmud Halidi, S. N. H. dan S. S. (2015). Pengaruh Media Pembelajaran Berbasis TIK terhadap Motivasi dan Hasil Belajar IPA Siswa Kelas V SDN Model Terpadu Madani Palu. E-Jurnal Mitra Sains, 3(1), 53-60.

Heni Rahmadani, Yenita Roza, A. M. (2018). Analisis Kebutuhan Bahan Ajar Matematika Berbasis Teknologi Informasi (TI) di SMA IT Al Bayyinah Pekanbaru. Juring (Journal for Research in Mathematics Learning), 1(1), 91-98. https://doi.org/http://dx.doi.org/10.24014/juring.v1 i1.5230

Heri Budiman, S. R. (2017). Pengembangan Bahan Ajar Matematika SMA Berbasis Geogebra Versi Android. Jurnal Science Tech, 3(2), 75-80. https://doi.org/http://dx.doi.org/10.30738/science\%20tech.v3i2.1607

Herlina, Edy Yusmin, A. N. (2017). Kemampuan Representasi Matematis Siswa Dalam Materi Fungsi di Kelas VIII SMP Bumi Khatulistiwa. Jurnal Pendidikan Dan Pembelajaran Untan, 6(10), 1-9.

Jeaniver Yuliane Kharisma, A. A. (2018). Pengembangan Bahan Ajar Matematika Berbasis Masalah Berorientasi pada Kemampuan Pemecahan Masalah Matematis dan Prestasi Belajar Matematika. Indonesian Journal of Mathematics Education, 1(1), 34-46.

Kartini Hutagaol. (2013). Pembelajaran Kontekstual untuk Meningkatkan Kemampuan Representasi Matematis Siswa Sekolah Menengah Pertama. Infinity, 2(1), 85-99. https://doi.org/https://doi.org/10.22460/infinity.v2i1.p85-99

Leo Adhar Effendi. (2012). Pembelajaran Matematika dengan Metode Penemuan Terbimbing untuk Meningkatkan Kemampuan Representasi dan Pemecahan Masalah Matematis Siswa. Jurnal Penelitian Pendidikan, 13(2), 1-10.

Muhamad Sabirin. (2014). Representasi Dalam Pembelajaran Matematika. Jurnal Pendidikan Matematika UIN Antasari, 1(2), 33-44. https://doi.org/10.18592/jpm.v1i2.49

Muhammad Khalifah Mustami, M. I. (2015). Pengembangan Lembar Kerja Peserta Didik (LKPD) Berorientasi Pendekatan Saintifik Pada Mata Pelajaran Biologi SMA. Lentera Pendidikan: Jurnal Ilmu Tarbiyah Dan Keguruan, 18(2), 236-247. https://doi.org/https://doi.org/10.24252/lp.2015v18n2a8

Musa Thahir, Yenita Roza, A. M. (2018). Validity of Learning Website of Kapita Selekta Mathematics Course at UIN Suska Riau Students. Malikussaleh Journal of Mathematics Learning (MJML), 1(1), 19-25. https://doi.org/https://doi.org/10.29103/mjml.v1i1.667

Oktaria, Sugeng Sutiarso, A. (2016). Pengembangan Bahan Ajar Matematika Berbasis Teknologi Informasi dan Komunikasi Bagi Siswa SMK. Jurnal Pendidikan Matematika Unila, 4(7). 
Rina Oktaviyanthi, Y. S. (2014). Pembelajaran Kalkulus Berbantuan Microsoft Mathematics. AdMathEdu, 2(2014), 173-190.

Rochmad. (2011). Model Pengembangan Perangkat Pembelajaran Matematika. UNNES.

Ruslan Saputra, Irham Falahudin, G. T. (2016). Pengembangan Bahan Ajar Matematika Berbasis Komputer untuk Siswa Kelas VIII di SMP Negeri 19 Palembang. Jurnal Pendidikan Matematika JPM RAFA, 2(249-268).

Salo, Y. A. (2017). Pengaruh Metode Discovery Learning terhadap Keaktifan Belajar Siswa (Studi Quasi Eksperimen Kelas VII SMPN 6 Banda Aceh). Jurnal Penelitian Pendidikan, 16(3), 297-304.

Saluky. (2016). Pengembangan Bahan Ajar Matematika Berbasis Web Dengan Menggunakan Wordpress. Jurnal EduMa, 5(1), 80-90. https://doi.org/10.24235/eduma.v5i1.685

Septia Wahyuni. (2012). Peningkatan Kemampuan Representasi Matematis dan Self EsteemSiswa Sekolah Menengah Pertama dengan Menggunakan Model PembelajaranArias.Univeritas Pendidikan Indonesia.

Shofura Farah Diba, Haninda Bharata, W. (2018). Pengaruh Model Discovery Learning terhadap Kemampuan Representasi Matematis Siswa. Jurnal Pendidikan Matematika Unila, 6(3), 236-247.

Siti Tuti Alawiyah, J. A. D. (2019). Peningkatan Kemampuan Representasi Matematis Siswa Kelas IC-G SMP Negeri 2 Bandung Pada Materi Persamaan Kuadrat dengan Discovery Learning Model. Jurnal Penelitian Dan Karya Ilmiah, 1(1), 38-46. https://doi.org/https://doi.org/10.33592/pe lita.Vol19.Iss1.72

Sri Rezeki. (2017). Meningkatkan Kemampuan Representasi Matematis Siswa Melalui Penerapan Model Pembelajaran Novick. Jurnal SAP, 1(3), 281-291. https://doi.org/http://dx.doi.org/10.30998/sap.v1i3.1203

Sukardi. (2008). Metodologi Penelitian Pendidikan, Kompetensi dan Praktiknya. Jakarta:PT. Bumi Aksara.

Syarifah Fadillah. (2011). Meningkatkan Kemampuan Representasi Multipel Matematika Siswa SMP Melalui Pembelajaran dengan Pendekatan Open Ended. Jurnal Pendidikan Matematika, 2(2), 100-107. https//doi.org/http://dx.doi.org/10.36709/jpm.v2i2.1966

Widya Kusumaningsih, R. P. M. (2017). Pengaruh Pembelajaran Berbasis Masalah dan Discovery Learning terhadap Kemampuan Representasi Matematis Siswa SMP. Jurnal Ilmiah

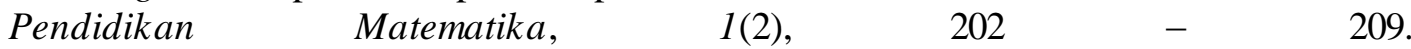
https://doi.org/http://dx.doi.org/10.26877/jipmat.v1i2.1247

Yusem Ba'ru. (2016). Pengaruh Penerapan Model Pembelajaran terhadap Hasil Belajar Matematika Ditinjau ari Minat Siswa Kelas VII SMP Negeri di Kota Rantepao. Jurnal Daya Matematis, 4(1), 83-89.

Yusmanto, T. H. (2017). Pengaruh Penerapan Model Pembelajaran Discovery Learning terhadap Peningkatan Kemampuan Berpikir Kritis Matematis dan Self Confidence Siswa Kelas V Sekolah Dasar. EduHumaniora https://doi.org/https://doi.org/10.17509/eh.v7i2.2705 